\title{
Fishery and stock status of cuttlefishes off Andhra coast, India with focus on the needle cuttlefish Sepia aculeata Van Hasselt, 1835
}

\author{
F. JASMIN ${ }^{1}$, M. MUKTHA ${ }^{1}$, S. GHOSH ${ }^{1}$, K. S. MOHAMED ${ }^{2}$, A. K. JAISWAR ${ }^{3}$, \\ P. LAXMILATHA ${ }^{4}$ AND LATHA SHENOY 3 \\ ${ }^{1}$ ICAR-Central Marine Fisheries Research Institute, Visakhapatnam Regional Centre, Visakhapatnam \\ Andhra Pradesh - 530 003, India \\ ${ }^{2}$ ICAR-Central Marine Fisheries Research Institute, Kochi - 673 005, Kerala, India \\ ${ }^{3}$ ICAR-Central Institute of Fisheries Education, Mumbai - 400 061, Maharashtra, India \\ ${ }^{4}$ ICAR-Central Marine Fisheries Research Institute, Madras Research Centre, Chennai, Tamil Nadu - 600003 , India \\ e-mail: lathashenoy@cife.edu.in
}

\section{ABSTRACT}

\begin{abstract}
The fishery and stock status of cuttlefishes along the northern coast of Andhra Pradesh was studied with special reference to the needle cuttlefish; Sepia aculeata Van Hasselt, 1835. Cuttlefishes caught by trawlers along the coast of Andhra Pradesh contributed $68.29 \%$ of the total cephalopod landings of the state during the study period (2006-2016). The average annual cephalopod landing in Andhra Pradesh for the study period was $2991 \mathrm{t}$ and the mean annual catch per hour (CPH) during 2006-2016 was $0.47 \mathrm{~kg} \mathrm{~h}^{-1}$. The cumulative sum (CUSUM) analysis indicated increasing trend in cuttlefish landings of the state during the study period. Stock status plots indicates that cuttlefish stocks along the Andhra Pradesh coast are in the "fully exploited" phase.
\end{abstract}

Keywords: Andhra Pradesh, CUSUM, Fishery management, Sepia aculeata, Stock status plot (SSP)

\section{Introduction}

Cephalopods are one of the significant components of the marine capture fisheries with unevenly distributed fisheries and landings in the world's oceans. According to Jereb et al. (2005), the total number of living species of cephalopods that have been described is fewer than 1000. However Rubaie et al. (2012), stated that about 700 species of cephalopods are distributed throughout the world oceans. Global landings of cephalopods have increased dramatically over the last 5 decades, rising from approximately 0.5 million $\mathrm{t}$ in 1958 (FAO, 1964) to over 4 million $\mathrm{t}$ in 2008 (FAO, 2010). Cephalopod landings now constitute almost $5 \%$ of the world's total fisheries production (FAO, 2010). More than 50\% of the total cephalopod catch is taken from the north-west Pacific and the south-west Atlantic. Other important areas are the western central Pacific, eastern Atlantic and eastern Pacific, but small-scale fishing activities in other areas also developed consistently in the past decades (FAO, 2000). Japan remains the leading cephalopod producing country, closely followed by China, Korea and Argentina. In 2001 alone Japanese fleets had landed over 5.6 lakh t of cephalopods, which was about $17 \%$ of the total world cephalopod catch. The demand for cephalopod import is huge in the south-east Asian countries as it is more sought after by the people. India is one of the main suppliers of cuttlefishes in international market other than Thailand, Spain, China, Argentina, Peru and Indonesia (FAO, 2016).

The average annual cephalopod production in India during the period 2001-2010 was 1.28 lakh $\mathrm{t}$. This is 3.41\% of the world production of cephalopods during the same period (Chakraborty et al., 2013). Molluscs contributed about $7 \%$ of the total marine landings (TML) of India during 2015-16 and cuttlefish contributed about $50 \%$ of the total cephalopod landings during the same period (CMFRI, 2016).

To frame a sustainable fishery management plan for a tropical country like India, having multispecies-multi-gear nature of fishery, it is necessary to assess the stock status of different species (Ghosh et al., 2015). During 2015-16, of the top five states in India contributing to the cephalopod landings, Andhra Pradesh (AP) ranked fourth contributing $1 \%$ of the mean annual marine landings (MAML) (2.95 lakh t). Gujarat contributed 8.73; Karnataka 6; Tamil Nadu 5.9 and Kerala $0.08 \%$ of MAML. The MAML of AP during 2000-2010 was 1.99 lakh t, of which molluses contributed 1.1\% (Maheswarudu et al., 2013). 
The main species of cephalopods exploited in Indian coast are Sepia pharaonis, S. aculeata, S. elliptica, S. brevimana, S. prashadi and Sepiella inermis. In Andhra coast, five species of cuttlefish are commercially exploited and among these $S$. aculeata is the most common species.

Information on the cephalopods resources in Indian waters are available from the works of Joseph (1966); Silas (1986); Silas et al. (1986); Sudarsan et al. (1988, 1990); Philip and Somvanshi (1991) and Kripa et al. (1996). Much of the previous research in India focused on the stock characteristics of $S$. aculeata occurring in different locations such as, by Menon (1988) from Mumbai waters; Rao et al. (1993) from all along the Indian Coast; Asokan (2000) along Malabar coast; Abdussamad et al. (2004) from Kakinada coast and Chakraborty et al. (2013) from north-west coast. Biology of this species was studied from Mangalore coast by Rao (1997) and Nalwa et al. (2005) from Mumbai coast. Oommen (1977) studied the structure of the alimentary canal, digestive enzymes and food and feeding habits of this species from the south-west coast of India.

Due to increase in demand and economic value, the landings of cephalopods have increased and if not managed properly, this can lead to decline of the fishery. Though having good fishery with increasing trend, there is no recent studies on the biology and fishery of cuttlefish from Andhra Pradesh coast especially that of $S$. aculeata. So the present study focused on the fishery and stock status of cuttlefishes with particular reference to the needle cuttlefish Sepia aculeata Van Hasselt, 1835 along Andhra coast.

\section{Materials and methods}

Annual estimates of both total cephalopods and cuttlefish landings in Andhra Pradesh recorded by the National Marine Living Resources Data Centre (NMLRDC) of ICAR-Central Marine Fisheries Research Institute (ICAR-CMFRI) for the years 2006-2016 were analysed and results are presented. Species level landings data was estimated from the weekly visits made to the Visakhapatnam Fishing Harbour $\left(17.7092^{\circ} \mathrm{N} ; 83.2707^{\circ} \mathrm{E}\right)$, the major trawl landing centre in Andhra Pradesh (Fig. 1). During the visits, the percentage contribution of different cephalopod species to the cephalopod landings of the day was estimated. This was then scaled up to the monthly and annual landings of cephalopods to obtain species-wise landing data.

The trend in landings of cephalopods and cuttlefish was studied using the Cumulative Sum (CUSUM) technique (Hurst, 1950). CUSUM is a visual statistical procedure commonly used in industry for quality control, which allows the detection of changes of a persistent process by time (Woodward and Goldsmith, 1964; Montgomery, 1991). It involves the subtraction of a control reference level from a series of points which was represented in this study by the average landing value of cuttlefish fishery over a certain time. CUSUM is calculated using the following equation (Barnard, 1959):

$$
S_{r}=\sum_{i=1}^{r}\left(x_{i}-\mu\right)
$$

where, ' $\mathrm{S}_{\mathrm{r}}$ ' is CUSUM, ' $\mathrm{x}_{\mathrm{i}}$, an individual time-series value and ' $\mu$ ' the long-term mean value of the time-series.

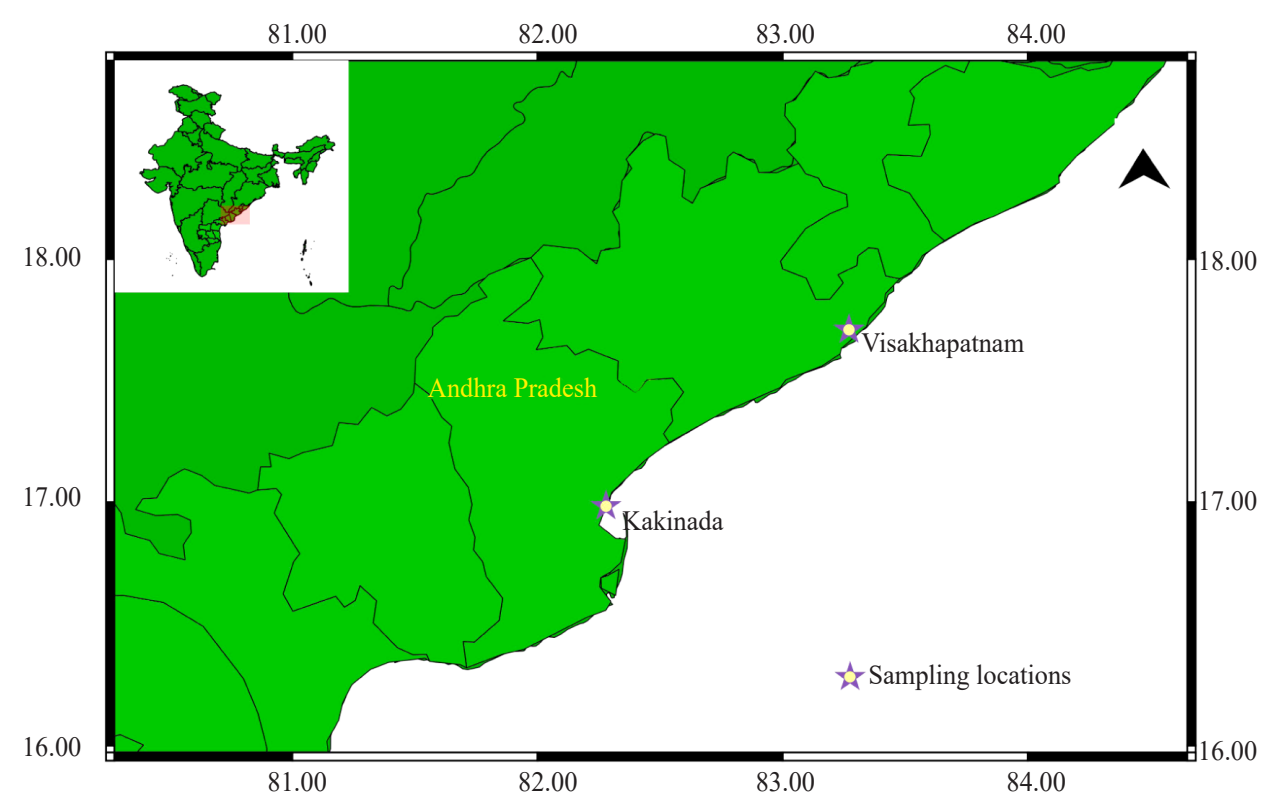

Fig. 1. Map showing the major cephalopod landing centres of Andhra Pradesh 
The goal of this exercise was to determine the point where the direction of change for each time series occurred. For example, a period of positive slope in the CUSUM chart indicates that values are above the long-term mean, whereas a period of negative slope indicates values that are below the long-term mean. The point at which the slope switches from positive to negative (or vice versa) is termed the change point (Dell'Apa et al., 2012).

Stock status of various species was studied using the stock status plots (Kleisner et al., 2013). 'Stock' in the present study is defined as time series of one species or group off Andhra coast for which the first and the last reported landings are at least 10 years apart and that there are at least 5 years of consecutive landings and for which the accumulated landings is at least (Kleisner and Pauly, 2011) $1000 \mathrm{t}$ (modified from the definition given by Pauly et al., 2008). To determine stock status in the given year, the species were classified into one of the following phases, i.e. i) 'developing', ii) 'fully exploited', iii) 'overexploited', iv) 'collapsed' and v) 'rebuilding' using the criteria given

Table 1. Criteria used to assign the exploitation stages based on landed catches $(\mathrm{C})$ relative to the maximum landed catch recorded in the time series $\left(\mathrm{C}_{\max }\right)$

\begin{tabular}{|c|c|}
\hline Status of fishery & Criterion applied \\
\hline Developing & Year before Year of $\mathrm{C}_{\max }$ and $\mathrm{C} / \mathrm{C}_{\max }<0.5$ \\
\hline Fully exploited & Year before/After Year of $\mathrm{C}_{\max }$ and $\mathrm{C} / \mathrm{C}_{\max }>0.5$ \\
\hline Overexploited & Year after Year of $\mathrm{C}_{\max }$ and $\mathrm{C} / \mathrm{C}_{\max } 0.1-0.5$ \\
\hline Collapsed & Year after Year of $\mathrm{C}_{\max }$ and $\mathrm{C} / \mathrm{C}_{\max }<0.1$ \\
\hline Rebuilding & $\begin{array}{l}\text { Years between collapsed and first subsequent } \\
\text { fully exploited }\end{array}$ \\
\hline \multicolumn{2}{|l|}{ Final Year rules } \\
\hline Developing & $\begin{array}{l}\text { If } \mathrm{C}_{\max } \text { occurs in the final year, increase } \mathrm{C}_{\max } \\
\text { by } 50 \% \text { and set its year of occurrence as final } \\
\text { year plus one }\end{array}$ \\
\hline
\end{tabular}

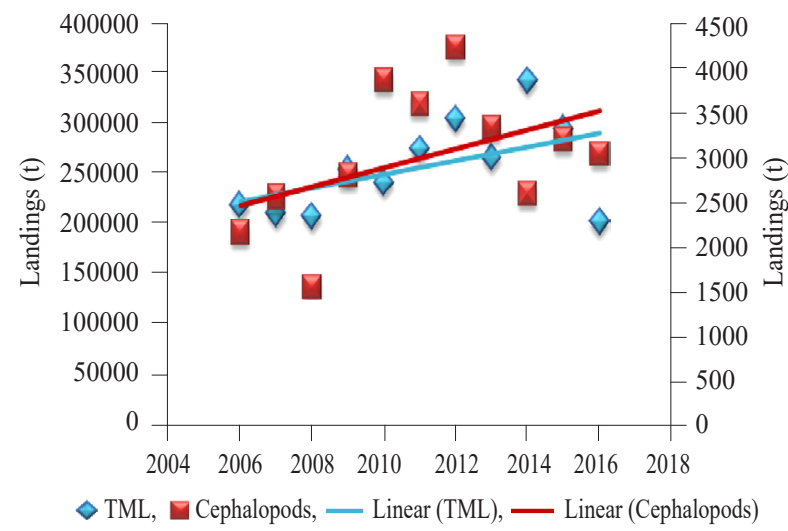

(a) in Table 1 (Froese and Kesner-Reyes, 2002; Froese et al., 2012; Kleisner et al., 2013).

\section{Results and discussion}

Fishery

The mean annual marine landings of Andhra Pradesh during 2006-2016 was 2,56,355 t. The maximum landings occurred during $2014(3,42,114 \mathrm{t})$ while minimum was in $2016(2,02,888 \mathrm{t})$. The cephalopod landing was highest in $2012(4,222 \mathrm{t})$ and lowest was in $2008(1,553 \mathrm{t})$. The average annual landing of cephalopods for the decade was about 2,991 t. Among cephalopods, cuttlefish contributed $66.9 \%$. The cuttlefish landings fluctuated widely with maximum landing in $2010(3,020 \mathrm{t})$ and minimum of $959 \mathrm{t}$ during 2008. Such fluctuations in landings of cephalopods have been reported from Kakinada (Abdussamad et al., 2004); Veraval and Mangrol (Thomas and Kizhakudan, 2006) and off Bombay (Sundaram, 2014). Cephalopod landings showed an increasing trend from 2006 to 2015 (Fig. 2a, b).

The gearwise contribution of cuttlefish landings from Andhra Pradesh showed that trawl was the major gear for their capture. About $94 \%$ of cuttlefish landed in AP was contributed by trawls, $2.2 \%$ by motorised gillnets, $1.7 \%$ by motorised ring seines, $0.6 \%$ by beach seines, $0.04 \%$ by hook and lines and $2 \%$ by other gears (Fig. 3). Trawl has traditionally been the major gear to land cuttlefish in the country (Rao et al., 1993, Abdussamad et al., 2004).

The results of CUSUM analysis for the landings (Fig. 4a) showed that the trend for cephalopod landing was similar to the cuttlefish landings for the decade (Fig. 4b) suggesting that cuttlefish were the major contributor among cephalopod catch in trawls. There were three changing points in the cuttlefish fishery where the slope switched from positive to negative value or vice versa.

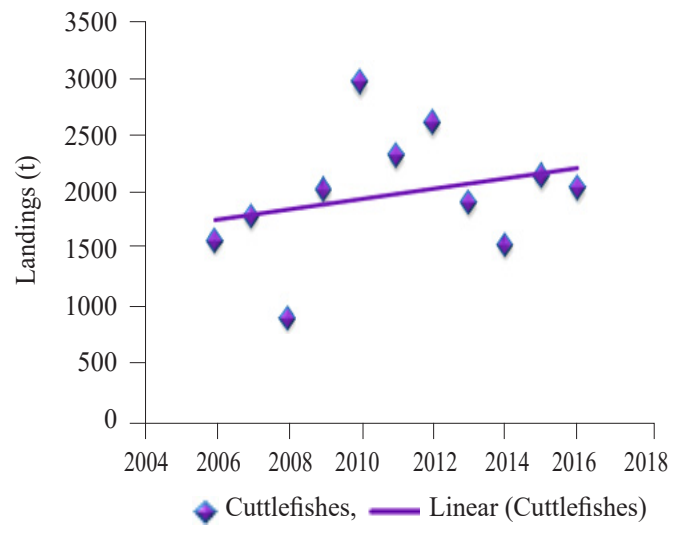

(b)

Fig. 2. Trend of (a) cephalopods and (b) cuttlefishes landings in Andhra Pradesh during 2006-2016 TML - Total marine landings 


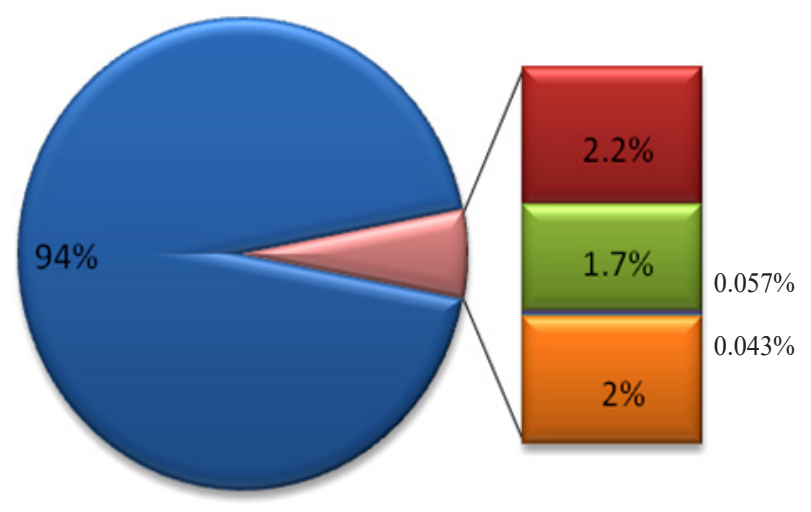

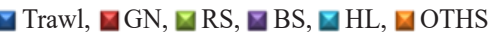

Fig. 3. Percentage contribution by gears to cuttlefish landed in Andhra Pradesh

GN-Gillnet, RS-Ring seine, HL- Hook and line, OTHS - Others

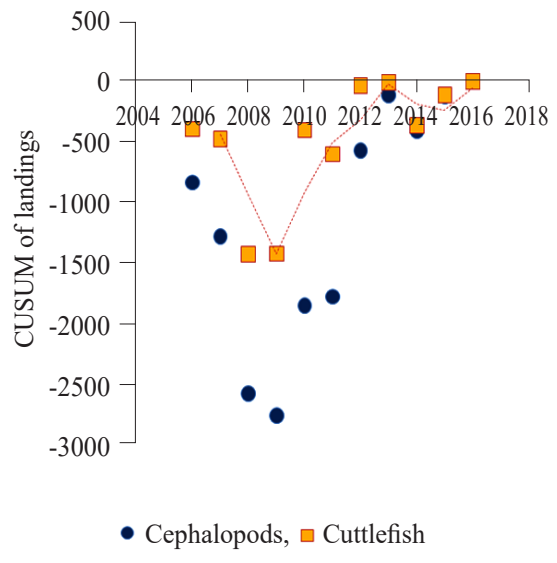

(a)
$57.20 \mathrm{~kg}$ unit $^{-1}$ and $\mathrm{CPH}$ of $0.61 \mathrm{~kg} \mathrm{~h}^{-1}$. The minimum exploitation of cuttlefish was during 2008 with a CPUE of $16.49 \mathrm{~kg}$ unit $^{-1}$ and CPH of $0.27 \mathrm{~kg} \mathrm{~h}^{-1}$. The CPUE showed an increasing trend (Fig. 5a) while CPH displayed a stagnant trend for cuttlefish landings in Andhra Pradesh (Fig. 5b).

The CUSUM for trawl CPUE of cuttlefish (Fig. 6) showed a fluctuating trend. It showed that even though the CPUE of trawl fishery was increasing in general, there was fluctuation in every two-three year period during 2006-2016.

The cuttlefish fishery of Andhra Pradesh comprised mainly of $S$. aculeata, S. pharaonis, S. brevimana, $S$. prashadi and $S$. inermis. The average percentage contribution of the species during 2006 to 2016 is

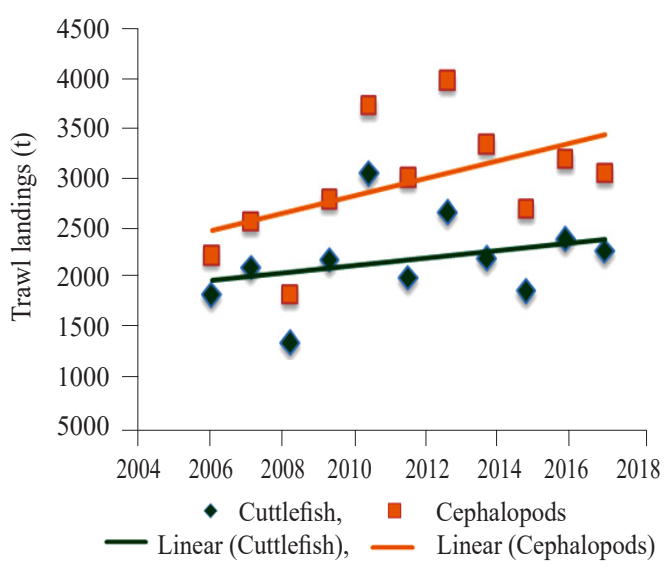

(b)

Fig. 4. (a) CUSUM and (b) trend for the trawl landings of cuttlefish in Andhra Pradesh

The average annual catch per unit effort (CPUE) for the period 2006-2016 was $34.75 \mathrm{~kg} \mathrm{unit}^{-1}$ and the catch per hour $(\mathrm{CPH})$ was $0.47 \mathrm{~kg} \mathrm{~h}^{-1}$. Maximum exploitation of cuttlefish was during 2015 with a CPUE value of

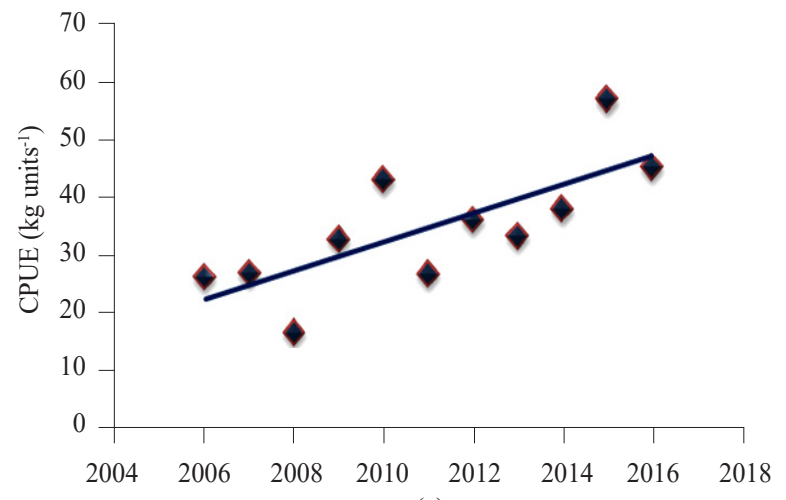

(a) shown in Fig. 7. S. aculeata dominated the cuttlefish fishery of Andhra Pradesh with a contribution of $33 \%$. $S$. aculeata contributed more to the cuttlefish landings during July-September and December-January.

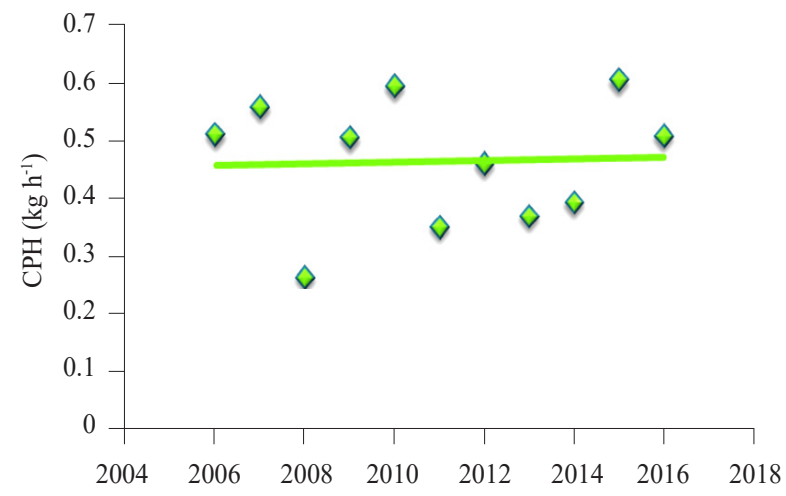

(b)

Fig. 5. Trends in (a) CPUE and (b) CPH of cuttlefish landed by trawls in Andhra Pradesh 


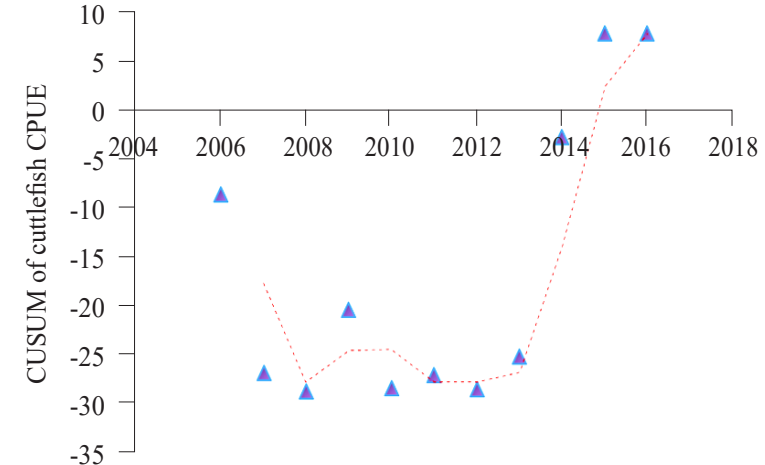

Fig. 6. CUSUM of annual CPUE of cuttlefish landed in trawls in Andhra Pradesh

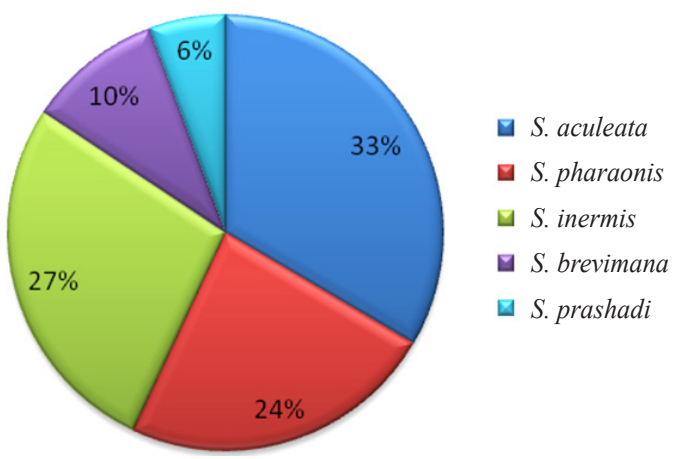

Fig. 7. Species-wise contribution of cuttlefish in Andhra Pradesh during 2006-2016

\section{Mean size}

A total of 2,688 samples of $S$. aculeata (Fig. 8; 9) were measured for length frequency determination. The total dorsal mantle length (DML) ranged between 85-212 mm with a mean value of $139.88 \mathrm{~mm}$. The DML of $79.69 \%$ of the samples measured were in the range $120-170 \mathrm{~mm}$.

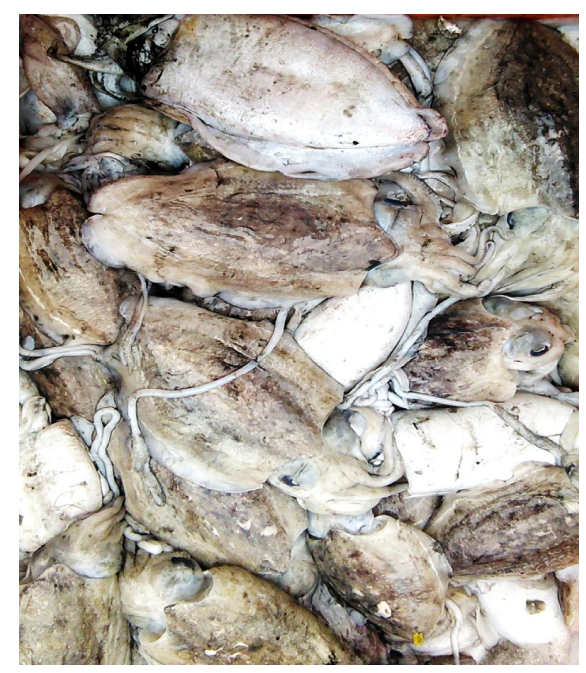

Fig. 8. S. aculeata landed at Visakhapatnam Harbour

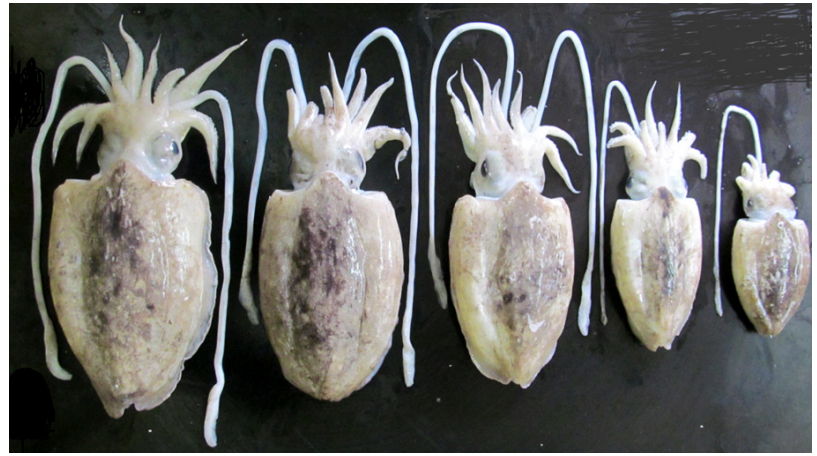

Fig. 9. Different size of S. aculeata landed at Visakhapatnam

The length frequency distribution is represented in Fig. 10 which clearly indicates that the length class from 120-170 mm dominated the fish landings of Andhra Pradesh. The length at maturity for the species is $140 \mathrm{~mm}$ (Jasmin et al., unpublished) which indicates that majority of the animals landed in AP are juveniles. Exploitation of juveniles results in considerable economic loss (Mohamed et al., 2014) and causes growth overfishing, leading to serious damage of the fish stock which in turn affects the long-term sustainability of the resources. Since the cephalopod as well as cuttlefish fishery of Andhra Pradesh showed an increasing trend with wide fluctuations, there is a chance of fishery decline in future if we increase the fishing effort. Moreover the stocks are in exploited state during recent years as per the stock status plot (SSP). So there is need to maintain the fishery in steady state by

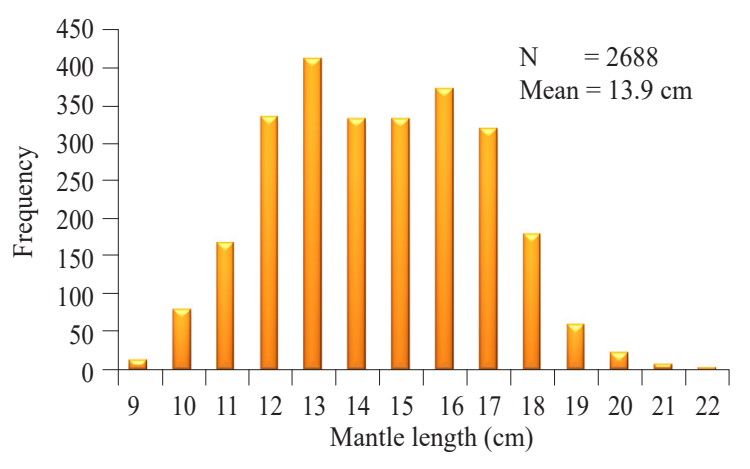

Fig. 10. Length frequency distribution of S. aculeata in Andhra Coast

restricting fishing effort and also by fixing a minimum legal size (MLS). MLS is a tool in fisheries management (Mohamed et al., 2014) that can regulate the sizes of fish caught which in turn would help to protect fish juveniles and conserve spawning stocks.

Stock status plot (SSP)

The stock status assessment of commercially exploited cuttlefish species from Andhra Coast is expressed as 
SSP (Fig. 11). During assessment years, all the species were mostly in the exploited phase Table 2. Only during some years certain species had gone beyond exploited phase and developing phase in certain years. S. aculeata was in exploited state in all the years of assessment except in 2007 where it had gone through developing phase. Since, currently the species is in the fully exploited state and its juveniles are heavily fished, there is a chance of stock collapse in the future if the fishery is not managed well by reducing the effort with strict implementation of optimum fleet size, mesh size regulations and minimum legal size. These will help in sustainable fisheries by maintaining the stock at healthy levels.

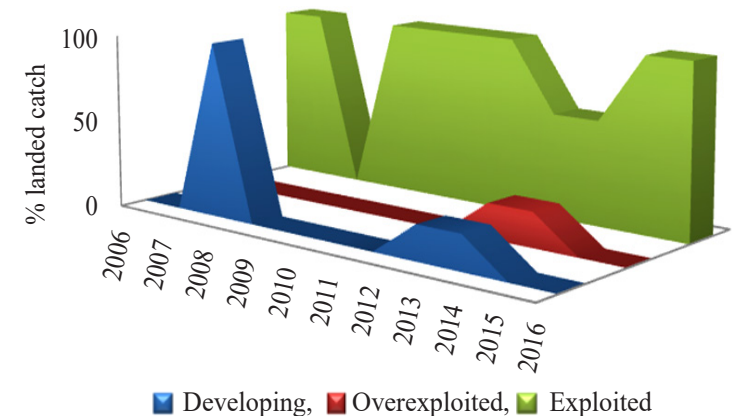

Fig. 11. Stock status plot by landed catch of cuttlefish species off Andhra coast during 2006-2016

Table 2. Stock status of landed catch of cuttlefish species off Andhra coast during 2015 and 2016

\begin{tabular}{lll}
\hline Species & 2015 & 2016 \\
\hline S. aculeata & Exploited & Exploited \\
S. pharaonis & Exploited & Exploited \\
S. inermis & Exploited & Exploited \\
S. brevimana & Exploited & Exploited \\
S. prashadi & Exploited & Exploited \\
\hline
\end{tabular}

\section{Acknowledgements}

The authors express their indebtedness to the Director, ICAR-CMFRI, Kochi, India as well as the Director, ICAR-CIFE, Mumbai, India, for their support. We extend our profound gratitude to Dr. Pratibha Rohit and Dr. G. Maheshwarudu for their contribution and support in analysing the fishery data of Andhra Pradesh.

\section{References}

Abdussamad, E. M., Meiyappan, M. M. and Somayajulu, K. R. 2004. Fishery, population characteristics and stock assessment of cuttlefishes, Sepia aculeata and Sepia pharaonis at Bangladesh. J. Fish. Res., 8(2): 143-150.

Asokan, P. K. 2000. Biology and fishery of cephalopods (mollusca: cephalopoda) along the Malabar coast. Ph. D. Thesis, University of Calicut, Kerala.
Barnard, G. A. 1959. Control charts and stochastic processes. J. R. Stat. Soc., 21: 239-271.

Chakraborty, S. K., Biradar, R. S., Jaiswar, A. K., Palaniswamy, R. and Kumar, P. 2013. Growth, mortality and population parameters of three cephalopod species, Loligo duvanceli (Orbigny), Sepia aculeata (Orbigny) and Sepiella inermis, (Orbigny) from north-west coast of India. Indian J. Fish., 60(3): 1-7.

CMFRI 2016. Annual Report 2015-16. Central Marine Fisheries Research Institute, Kochi, 294 pp.

Dell'Apa, A., Kimmel, D. G. and Clo, S. 2012. Trends of fish and elasmobranch landings in Italy: associated management implications. ICES J. Mar. Sci., 69(6):1045-1052. doi:10. 1093 /icesjms/fss067.

FAO 1964. FAO year book. of fisheries statistics: Catches and landings 1963, vol. 16. Food and Agricultural organisation, Rome, Italy.

FAO 2000. FISHSTAT Plus: Universal software for fishery statistical time series,Version 2.3. Fisheries Department, Fishery Information, Data and Statistics Unit. Capture production 1950-2001. http://www.fao.org/fi/statist/fisoft/ fishplus.asp.

FAO 2010. FAO year book of fishery and aquaculture statistics. 2008. Fisheries and Aquaculture Information and Statistics Service, Technical report, Food and Agricultural Organisation, Rome, Italy..

Froese, R. and Kesner-Reyes, K. 2002. Impact of fishing on the abundance of marine species. ICES CM 2002/L: 12, Copenhagen, $15 \mathrm{pp}$.

Froese, R., Zeller, D., Kleisner, K. and Pauly, D. 2012. What catch data can tell us about the global status of fisheries. Mar. Biol., 159(6): 1283-1292.

Ghosh, S., Muktha, M., Rao, M. V. H. and Behera, P. R. 2015. Assessment of stock status of the exploited fishery resources in northern Bay of Bengal using landed catch data. Indian $J$. Fish., 62(4): 23-30.

Hurst, H. E. 1950. Long-term storage capacity of reservoirs. Proceedings of the American Society of Civil Engineers, 76: 1-30.

Jereb, P., Roper, C. F. E. and Vecchione, M. 2005. Cephalopods of the world. An annotated and illustrated catalogue of species known to date. In: Jereb, P. and Roper, C. F. E. (Eds), Chambered nautiluses and sepioids (Nautilidae, Sepiidae, Sepiolidae, Sepiadariidae, Idiosepiidae and Spirulidae). FAO Species Catalogue for Fishery Purposes. No. 4, vol. 1. FAO, Rome, p. 1-19.

Joseph, K. M. 1966. Some observations on potential fishery resources from the Indian EEZ, Bull. Fish. Surv. India, 14: 1-20.

Kleisner, K. and Pauly, D. 2011. Stock-catch status plots of fisheries in regional seas. The state of biodiversity and fisheries in regional Seas. Fish Centre Res. Rep., 19(3): 37-40. 
Kleisner, K., Zeller, D., Froese, R. and Pauly, D. 2013. Using global catch data for inferences on the world's marine fisheries, Fish Fish., 14: 293-311.

Kripa, V., Nair, K. P., Vidyasagar, K., Rao, G. S., Lipton, A. P., Appukuttan, K. K., Srinivasan, P. V., Rajapandian, M. E., Natarajan, P., Ramadoss, K., Burayya, N., Thomas, K. T., Achayya, P., Bhaskaran, M. M. and Joseph, M. 1996. Cephalopod resources in south-east and north-east coasts of India and Andaman-Nicobar waters. In: Pillai, V. K., Abidi, S. A. H., Ravindran, V., Balachandran, K. K. and Agadi, V. V., (Eds.), Proc Second Workshop Scient. Resul. FORV Sagar Sampada, 445 pp.

Maheswarudu, G., Rao, G. S., Rohit, P., Laxmilatha, P., Ghosh, S. and Muktha, M. 2013. Marine fisheries of Andhra Pradesh: a decadal analysis. Indian J. Fish., 60(3): 27-33.

Menon, N. R. 1988. Morphometry and population dynamics of Sepia aculeata (Orbigny, 1848) along the Bombay Coast. J. Indian Fish. Ass., 18: 475-481.

Mohamed, K. S., Zacharia, P. U., Maheswarudu, G., Sathianandan, T. V., Abdussamad, E. M., Ganga, U., Pillai, S. L., Sobhana, K. S., Nair, R. J., Jose, J., Chakraborty, R. D., Kizhakudan, S. J. and Najmudeen, T. M. 2014. Minimum legal size (MLS) of capture to avoid growth overfishing of commercially exploited fish and shellfish species of Kerala. Mar. Fish. Inf. Serv.; $T \&$ E Ser., 220: 3-7.

Montgomery, D. C. 1991. Introduction to statistical quality control, $2^{\text {nd }}$ edn. John Wiley and Sons, New York.

Nalwa, M. K., Kumar, R., Jaiswar, A. K. and Swamy, R. P. 2005. Morphometry, length-weight relationship and biology of Sepia aculeata (d' Orbigny, 1848) from Mumbai coast, India. J. Indian Fish. Ass., 32: 19-27.

Oommen, V. P. 1977. Studies on the food, feeding and fishery of certain cephalopods from the west coast of India. Bull. Dept. Mar. Sci. Univ. Cochin, 8: 73-152.

Pauly, D., Alder, J., Booth, S., Cheung, W. W. L., Christensen, V., Close, C., Sumaila, U. R., Swartz, W., Tavakolie, A., Watson, R., Wood, L. and Zeller, D. 2008. Fisheries in large marine ecosystems: descriptions and diagnoses In: Sherman, K. and Hempel, G. (Eds.), The UNEP Large Marine Ecosystem Report: A perspective on changing conditions in LMEs of the world's regional seas. UNEP Regional Seas Reports and Studies. UNEP, Nairobi, Kenya, p. $23-40$.

Philip, K. P. and Somavanshi, V. S. 1991. Squid and cuttlefish resources of the Indian continental shelf and slope; Proc. Nat. Workshop. Fish. Resour. Data. Fish. Indusr, p. 88-97.

Rao, G. S. 1997. Aspect of biology and exploitation of Sepia aculeata Orbigny from Mangalore area, Karnataka, Indian J. Fish., 44(3): 247-254.

Rao, K. S., Srinath, M., Meiyappan, M. M., Nair, K. P., Sarvesan, R., Rao, G. S., Natarajan, P., Vidyasagar, K., Sundaram, K. S., Lipton, A. P., Radhakrishnan, G., Narasimha, K. A., Mohamed, K. S., Balan, K., Kripa, V. and Sathyanandan, T. V. 1993. Stock assessment of the needle cuttlefish Sepia aculeata. Indian J. Fish., 40(1 \& 2): 95-103.

Rubaie, Z. M., Idris, M. H., Abu Hena, M. K. and King, W. S. 2012. Diversity of cephalopod from selected division of Sarawak, Malaysia. Int. J. Advan Sci., Eng. Inf. Technol., 2(4): 8-10.

Silas, E. G. 1986. Cephalopod resources: Perspective priorities and targets for 2000 A. D., Bull. Cent. Mar. Fish. Res. Inst., 37: $172-183$.

Silas, E. G., Vidyasagar, K., Nair, K. P. and Rao, N. 1986. Cephalopod resources revealed by exploratory surveys in Indian seas, Bull. Cent. Mar. Fish. Res. Inst., 37: 129-136.

Sudarsan, D., John, M. E. and Somavanshi, V. S. 1990. Marine fishery resources potential of the indian exclusive economic zone - an update. Bull. Fish. Surv. India, 20: 27 pp.

Sudarsan, D., Sivaprakasam, T. E., Somavanshi, V. S., John, M. E., Nair, K. N. V. and Joseph, A. 1988. An appraisal of the marine resources of the Indian EEZ. Bull. Fish. Surv. India, 18: 85 pp.

Sundaram, S. 2014. Fishery and biology of Sepia pharaonis Ehrenberg, 1831 off Mumbai, north-west coast of India. J. Mar. Biol. Ass. India, 56(2): 43-47.

Thomas, S. and Kizhakudan, S. J. 2006. Cephalopod fishery and population dynamics of Loligo duvauceli (Orbigny) off Saurashtra region, Gujarat. Indian J. Fish., 53(4): 425-430.

Woodward, R. H. and Goldsmith, P. L. 1964. Cumulative sum techniques. ICI Monograph 3. Oliver and Boyd, Edinburgh. 